\title{
SONGS BY WITOLD FRIEMANN SET TO THE POEMS of Taras Shevchenko: Polish-Ukrainian INSPIRATIONS IN ART
}

A dialogue of cultures, understood to mean the interaction between different artistic traditions, may assume various forms. In the case of musical expression it is reflected in both the assimilation of foreign artistic conventions as well as in the co-writing of works which combine elements from the cultural heritages of authors of different origins. When the object of analysis is Polish musical culture in the $19^{\text {th }}$ and $20^{\text {th }}$ centuries in the context of its infiltration by various elements of Ukrainian culture, both these forms of acculturation can be identified in the musical artifacts of certain Polish composers of the time.

Key words: art song, Witold Friemann`s music, poems by Taras Shevchenko.

Problem statement In the field of musical creation, the phenomenon of such interaction is realized both through the assimilation of foreign artistic conventions and the creation of works that, as it appear, blend elements of cultural heritage of different origins of authors on national spaces.

The above forms of acculturation are always traced in musical artifacts, especially when the subject of discussion is the Ukrainian component in the Polish musical culture of the $19^{\text {th }}$ and $20^{\text {th }}$ centuries. A vivid embodiment of the Polish-Ukrainian dialogue are Songs for Voice and Piano Op. 18 and Op. 26 by Witold Friemann, written to poems by Taras Shevchenko during the First World War (1916-1917).

Analysis of recent research. It should be noted that the question of the influence of certain artistic examples of the heritage of Ukrainian culture has not yet been fully disclosed. But among researches the problem of interaction between different cultures in artistic trends should be distinguished by such scholars as M. Tomaszewski [10], E Nidecka [7], T. Ulewicz [12]. The author of this research offers to consider the dialogue of cultures of Ukraine and Poland through an analysis of the forms of embodiment of traits of traditional art. Draws attention to thoughts of $\mathrm{T}$. Chylińska [1], M. Jakóbiec [3], M. Janion [4], M. Tomaszewski [8; 9].

Main objective of the study is to discover and explore the cultural and biographical aspects of the appearance of a musical work using the poetry of the Ukrainian poet [A. Mitscha, 6]; to determine influence of elements of culture heritage of foreign national artists; to consider the concept of a composer`s plan on the example of the set of songs of Witold Friemann to the poems of Taras Shevchenko [M. Tomaszewski, 11; 12].

Cultural contexts of the dialogue. The ability of Ukrainian culture to "percolate" into the works of various Polish composers can be explained by a number of elements inherent within it. These were determined by time, place, and the history of both nations. The $19^{\text {th }}$ century was an age in which Romanticism reigned supreme in the spiritual culture of Europe. This was an ideological and artistic movement that promoted the ennoblement of folk culture through its elevation to the ranks of universal European culture [4, 297-302]. In Polish society at that time the ideas of Romanticism were intertwined with the ethos of romantic Sarmatism [13, 336-337]. This term refers to the spiritual culture and customs of the old Polish-Lithuanian Commonwealth, a kingdom

(C) A. Novak, 2018.

https://doi.org/10.31318/0130-5298.2018.44.0.152719 
which, for several centuries, was built on the political union of the Polish, Lithuanian, and Ruthenian nations. The desire of the Polish nobility to cultivate Sarmatic values and customs on their estates in Volhynia, Podolia, Lithuania, Belarus, and Ukraine was motivated by a desire to preserve their national identity after Poland had been erased from the map of Europe in 1795. When we consider the weight of these two ideological tendencies (Romanticism and Sarmatism) and take into account the effects of the loss of Polish independence, i.e. the forced observance of foreign laws, the numerous attempts by Poles to regain sovereignty (via national uprisings) which, in turn, led to involuntary exile, as well as the search for the roots of a national culture and other cultures that emerged in the former Commonwealth, appear to have been a logical consequence of the above-mentioned events. Maria Janion, an expert in the field of Polish Romanticism, characterized this phenomenon with the following words:

"The young Romantics, assured of the power of spirit as a decisive motor of change [were] certain that empirical violence <...> may and should be resisted for spiritual reasons and using values which would undoubtedly triumph in the future" [4, 299].

The above interpretation of the factors that shaped the character of literary and musical works in the $19^{\text {th }}$ century refers not only to the output of Polish poets, writers and composers, but also to those writers and artists who contributed to Ukrainian national culture, among them Taras Shevchenko (1814-1861).

One of the most important elements of Ukrainian musical culture that marked its presence in the music of many Polish composers during the Romantic period was the dumka [10, 13-333]. As a song with a melancholic-nostalgic mood, expressing regret or a longing for a lost person, place or environment, it inspired several generations of composers. Appearing as early as in the songs of Fryderyk Chopin to signify "the genre most suitable for expressing the content and expression <...> of texts somewhat mournful and melancholic" $[8,536]$. Mieczysław Tomaszewski, whose words I have just quoted, treats dumkas as idyllic songs of a non-dance type, "in which $\langle.$. > folk influences (Polish and Ukrainian) clash with romantic ones" [9, 102]. It is significant that five of the songs in this cycle («Dumka», «Witchcraft», «Spring», «The Messenger», «The Twofold Ending») were composed by Chopin in Paris to the words of Stefan Witwicki and Bohdan Zaleski, two Polish emigrés born in Ukraine (Witiwcki born in the Podolia region, Zaleski born in the Kiev Governorate). In its stylized form as an art-song of folk provenance the dumka also found its way into the works of the next generation of composers: appearing in lyrical vocal pieces by Stanisław Moniuszko (the songs «Cossack», «The Song of Podolia», «Dumka» and others), Zygmunt Noskowski (solo songs, piano and violin pieces) and Eugeniusz Pankiewicz (the song «Dumka»), and, at the beginning of the $20^{\text {th }}$ century, also in songs composed by Witold Friemann.

A biographical note to explain the creation of Song Op. 26. In the works of Witold Friemann (1889-1977), a composer who remained faithful to the ideas of romantic art throughout his creative life, the dialogue with Ukrainian culture comes to the fore in the music he composed during the First World War. Friemann was born and raised in Konin [6], the seat of Konin Powiat (an administrative unit equivalent to a county), in central Poland, which in his youth was located in the western part of Tsarist Russia. The composer's relatives included a number of outstanding musicians: the violinist and composer Gustaw Friemann and Włodzimierz Friemann - a professor of piano in Rostov-on-Don. His mother - Maria née Brodowska - was related to Antoni Brodowski, "the leading Polish representative of classicism in painting" [6, 8]. Witold Friemann received his musical education at the Musical Institute in Warsaw (graduating with a diploma in composition under Zygmunt Noskowski, and a diploma in the piano under Aleksander Michałowski in 1909) and the Conservatory of Music in Leipzig (graduating with a diploma in composition under Max Reger, and a diploma in piano under Joseph Pembauer, Jr. in May 1914). He would spend the summer months of the school holidays away from the conservatory, mostly at his uncle Józef Brodowski's house in Iwankiwci, on the River Zbruch, which is where he found himself at the 
outbreak of World War I in 1914. This event interrupted the promising career of the young pianist who, as a subject of the Tsar, was conscripted into the army. He was assigned to a regiment of Lifeguard sappers in the Caucasus. In 1916 he was discharged from the army due to injury and exhaustion brought on by illness. He headed for Płoskirów (today Khmelnytskyi, Ukraine) near Kamianets-Podilskyi, where he was awaited by his family - his mother and her brother Józef Brodowski, and where - as the composer's biographer Adam Mitscha wrote - he "survived seven sieges and changes of power" [6,24]. In a later memoir, Friemann recalled the following facts from that dramatic period of his life:

"Back then, I used to live in Płoskirów in Russian Podolia. It was a time of great revolutionary upheaval in the territory of the former tsarist Empire. Płoskirów would pass from one side to the other repeatedly. At one time it would be taken over by the Petliura people, then by Kornilov troops. Then, on several occasions, it was seized by the Bolsheviks. The Ukrainians ruled over it occasionally $\langle\ldots>$ Then, finally, the Poles set up camp there for a while longer $<\ldots>$ We existed in a kind of vegetative state in this apparently peaceful climate: my mother, her brother Józef Brodowski and I, practically living day to day, waiting for what an uncertain tomorrow might bring" $[6,24]$.

In those dramatic days of "apparent" peace, whenever the situation in a city constantly being invaded by different military factions allowed, Friemann "escaped" into the world of music. He would compose. It was in this atmosphere that he created his 4 opuses for voice and piano (Op. 18, 19, 25, and 26) as well as his «Elegy» for viola and piano. The prevalence of vocal music over instrumental pieces leads us to believe that for the composer himself poetry was as equally an important means of artistic expression at that moment as sound itself. During his stay in Płoskirów, i.e. between the end of 1916 and 1918, Friemann found creative impulses in the verses of Kazimierz Przerwa-Tetmajer, Shevchenko, Wierzbicki, Grochólski, and Kusznierewska. Most of his songs were set to poems by Przerwa-Tetmajer and Shevchenko (six each) ${ }^{1}$.

One may inquire as to the motivations behind the choice of these poets. Kazimierz PrzerwaTetmajer's appeal is quite easy to explain. As a "classical exponent of neo-Romantic lyricism" [2; 5], and at the same time a "representative of the lyrical poetry of the 'Young Poland' movement" $[2 ; 5]$ at the turn of the $20^{\text {th }}$ century Przerwa-Tetmajer struck a chord with many Polish readers. Among those who found themselves fascinated by his poetry was Witold Friemann, who remained so throughout his life. Most of his songs were sets to Przerwa-Tetmajer's words.

And what about his fascination with Shevchenko's poetry? It turned out to be a one-off. In his later years, the composer did not return to the Ukrainian bard for inspiration. This peculiar diversion in Friemann's creative journey is not easy to explain. There is, unfortunately, a lack of fully documented information on this topic, and the events recalled by the family are quite imprecise. We can, therefore, presume that the coincidence of several favorable factors must have occurred, the most important of which was access to the published volumes of the poet's works. In Płoskirów, a city caught up in the middle of the revolutionary fighting, the only resources that could be counted on were those to be found in the local library collection. What is known from the surviving manuscripts is that Friemann decided to use the original (Ukrainian) texts of Shevchenko's poems, having translated three of them into Polish himself («Girl», «Little Ladies” Shoes», «Cuckoo»). This allows us to conclude that the private collection of the Brodowski family most probably included a book of Shevchenko's poems. Podolia was a region where Ukrainian and Polish culture developed side by side. The houses of Polish landowners contained the published works of Polish and Ukrainian literature, both in the original and in translation. Further proof of this

\footnotetext{
${ }^{1}$ See: Appendix. Songs by Witold Friemann to poems by Taras Shevchenko.
} 
are Polish translations of Shevchenko's poems. Let us recall that the first Polish translations of the poems by the author of «Kobzar» appeared in print in Vilnius in 1860 and 1861. His poetry was also published in Kiev (1862) and Lviv (1963). An edition of Shevchenko's Selected Poems translated by the Ukrainian poet Sydir Tverdokhlib [3, 126], which appeared in 1913 (just before the outbreak of World War I) in Lviv, became a major publishing event. The popular reception of Shevchenko's poetry in enlightened circles in Polish society explains the availability of his poems in a small town in Podolia that at the time found itself at the heart of revolutionary turmoil.

The artistic motivation behind Friemann's choice of specific poems by Shevchenko. Friemann's selection of poetic texts suggests a number of additional motivating factors. Six poems by Shevchenko represent two expressive and semantic modes. The first comprises poems of a nostalgic nature, with a reflexive and philosophical content («Songs of Mine», «A Memory», «Lullaby»), while the second modus refers to the poetics of folk poetry, depicting the world of a village girl's feelings («Little Ladies' Shoes», «Girl», «Cuckoo»). The former is an expressive category defined by the Italian words lyrico - elegiaco, the latter is an expressive category of rustico - choreico.

Equally significant was the choice of the poem «Songs of Mine» and the placing of the resulting song with the same title in first position in Opus 26. This verse, following its inclusion in «Kobzar» in 1840, emerged as the manifesto of national Ukrainian literature. Ivan Franko wrote of it: "[it] burst like the source of pure, refreshing water, shining with a hitherto unknown brilliance, simplicity and poetic grace of expression" [3,53]. Marian Jakóbiec, the author of an academic study of the Polish edition of Shevchenko's poems published in $1974^{1}$, characterized the poem's message as follows: "It is an honest confession of an artist thrown into a foreign land, a man who felt the burden of national responsibility deep inside of him" [3, 46].

Friemann's decision to set this poem to music does not seem to have been an arbitrary one. It was a reaction to the spiritual values of Shevchenko's poetry that the composer happened to share. It can thus be fairly safely concluded that «Songs of Mine» was composed as an artistic manifesto reflecting Friemann's experiences and impressions that inspired him to turn this very poem into a musical piece. Modern semiotic theories claim that a musical work can function as a representation of the author's "inner" reality. There are many indications that «Songs of Mine» carries "traces of experiences in the field of his emotional life and <...> reflections of the experiences of spiritual life" $[11,11]$.

The elegiac character of Songs of Mine was born out of an attempt to adjust musical means of expression to their poetic equivalents. The scale of $\mathrm{D}$ minor, which in the past had been chosen by composers to convey content from the sphere of metaphysics and the deepest existential experience, coexists here alongside a triple-meter, Andante ma non troppo tempo and musical narrative with an expansive expressive arch conveyed by melodic and harmonic devices. The songs: "A Memory» (E minor scale, ${ }_{4}^{3}$ meter) and «Lullaby» (D minor scale, ${ }_{4}^{3}$ meter) are kept in a similar mood, with a preference for minor scales, a steady tempo and a lyrical-nostalgic mood.

A musical response of the sensual type ${ }^{2}$, however, can be found in the songs «Little Ladies' Shoes», «Girl», and «Cuckoo»/《Zazula». These are musical reflections of the reality present in the second group of Shevchenko's poems. The sensory response is indicated by the onomatopoeic and metonymic means used to express through music the reflex of the world embodied in the poem, e.g.

\footnotetext{
${ }^{1}$ Taras Shevchenko. Wybór poezji [Selected poems], Wrocław 1974.

2 This category used to describe non-musical representation was inspired by: Mieczysław Tomaszewski [12].
} 
imitating a cuckoo's voice, dance gestures, etc. These songs can be read as a "representation of external reality $\langle\ldots\rangle$ its reflections, reflexes, relics or echoes" $[11,13]$.

Other aspects of the musical interpretation of the poems. The manner in which Friemann read and interpreted Shevchenko's poems through music can also be considered from the perspective of the stylistic devices applied and existing artistic conventions. The musical language of these compositions, i.e. major-minor tonality (minor key songs predominate), functional harmonies using complex chord combinations, textures typical of neo-Romantic songs, musical syntax built from musical statements forming expressive arches, most of the songs with an $\mathrm{ABA}_{1}$ reprise structure - all of these measures point to the traditions of European vocal lyricism, especially the German Lied. The composer did not attempt to imitate the specific aura of Ukrainian folk music. «Songs of Mine» highlights the variety encapsulated by the European art-song, maintaining the expressive climate of the folk original, whereas in the case of other musical poetics it was inspired by the artistic means characteristic of European music in the $19^{\text {th }}$ and early $20^{\text {th }}$ centuries. The same stylistic categories provide structure to the other songs in Opus 26.

Shevchenko's poetic works were described by Marian Jakóbiec in the following manner: "The poet usually refused to shape his works according to folk models. Instead, as Maksym Rylski pointed out, he would exploit the folk song for the sake his own artistic ideas, <...> compliant $<\ldots .>$ with his own poetic vision" [3, 43-44].

In light of the above statement, we begin to see a convergence between the poet's and composer's creative outlooks. The cultural filter that both imposed on the form of their artistic message, defined the nature of the created works. Both the poetry of Taras Shevchenko and the songs of Witold Friemann expressed a desire to co-create a universal tradition of European culture, to become part of it, instead of simply offering a testimony to a regional cultural heritage; this goal was definitely achieved.

Reception of the songs. When the revolutionary fighting began to calm down and World War I neared its end, Friemann received a visit in Płoskirów from Piotr Smerecki, an envoy acting on behalf of the Polish musicologist Professor Adolf Chybiński from Lviv. Friemann was offered the opportunity to teach a piano concerto class and act as a substitute professor of composition at the Conservatory of the Polish Musical Society as well as fill a teaching post at the Jan Kazimierz University [6, 24-25].

The songs Friemann composed in Płoskirów were met with great acclaim by musicians and audiences alike in Lviv. They were performed by the most prominent singers of the time, one of whom was Stanisława Korwin-Szymanowska, Karol Szymanowski's sister, who repeatedly declared to audiences that the song «Girl» was the "showpiece" of her repertoire [1, 24-25]. After World War II, when the musical themes and ideas of the avant-garde seized the imaginations of both Polish composers and music critics, the neo-romantic vocal lyrics of Friemann were forgotten. It was not until the turn of the $21^{\text {st }}$ century that interest in his work was revived, thanks to the vocal competition "Slavic Vocal Music and Beyond" organized in Katowice.

Source research recently carried out by Ewa Nidecka [7] showed that Witold Friemann's songs for voice and piano Op. 18 and Op. 26 were most probably the only vocal lyrical poems set to the words of Taras Shevchenko and written by a Polish composer in the first half of the $20^{\text {th }}$ century. The story of how they came to be composed reflects the complicated history of Polish and Ukrainian musical culture as well as the unique coincidences that occasionally shaped the genesis of individual works by Polish and Ukrainian artists.

Conclusions and results of the research. The revealed factors influence the formation of the nature of selected musical pieces of Polish composers of the $19^{\text {th }}$ century. The signs of the genre of the Ukrainian Duma, which, thanks to the analysis, were found in the works of Polish composers 
such as Stanisław Moniuszko, Zygmunt Noskowski and Eugeniusz Pankiewicz, give grounds to testify to the influence of Ukrainian melodious in the embodiment of the composer`s plan. The artistic motivation of choosing and using Taras Shevchenko's poetry in the songs of Witold Friemann is described in the context of the phenomenon of interpretation and the influence of both cultures.

\section{SOURCES}

1. Witold Friemann, Song for voice and piano «Dziewczyna» Op. 18 No. 2, manuscript in the possession of the composer's family.

2. Witold Friemann, Songs for voice and piano Op. 26 No 1-5, manuscripts in the possession of the composer's family.

3. Taras Shevchenko. Wybór poezji [Selected poems], Wrocław 1974.

\section{REFERENCES}

1. Chylińska T. (2008), Karol Szymanowski i jego epoka [Karol Szymanowski and his era], vol. 2, Musica Iagellonica, Krakow.

2. Jabłońska K. (1969), Kazimierz Tetmajer. Próba biografii [Kazimierz Tetmajer. An attempt at a biography], Wydawnictwo Literackie, Krakow.

3. Jakóbiec M. (1974), Introduction, in: Taras Shevchenko. Wybór poezji [Selected poems], Ossolineum, Wrocław, pp. 3-134.

4. Janion M. (1985), Romantyzm [Romanticism], in: Literatura Polska. Przewodnik encyklopedyczny [Polish Literature. A Thesaurus], vol. 2, Państwowe Wydawnictwo Naukowe, Warsaw, pp. 297-302.

5. Krzyżanowski J. (1968), Introduction, in: K. Tetmajer, Poezje wybrane [Selected poems], Ossolineum, Wrocław, pp. 3-104.

6. Mitscha A. (1980), Witold Friemann. Życie i twórczość [Witold Friemann. Life and Music], Zeszyt Naukowy 17, Akademia Muzyczna w Katowicach [Academic Papers 17, Academy of Music in Katowice], Katowice.

7. Nidecka E. (2005), Twórczość polskich kompozytorów Lwowa a ukraińska szkoła kompozytorska: 1792-1939 [The work of Polish composers of Lviv and the Ukrainian compositional school: 1792-1939], Wydawnictwo Uniwersytetu Rzeszowskiego, Rzeszów.

8. Tomaszewski M. (1998), Chopin. Człowiek. Dzieło. Rezonans [Chopin. The Man. The Work. The Resonnance], Raniowski, Podsiedlik i Spółka, Poznań.

9. Tomaszewski M. (1996), Muzyka Chopina na nowo odczytana. Studia i interpretacje [A New Reading of Chopin's music. Studies and interpretations], Akademia Muzyczna w Krakowie, Krakow.

10.Tomaszewski M. (2017), Ślady I echa idiomu kresowego w muzyce polskiej "wieku uniesien" [Traces and Echoes of a "Kresy" Idiom in the Polish Music of the "Age of Raptures"], in: Teoria Muzyki. Studia, Interpretacje, Dokumentacje 10 [Theory of Music. Studies, Interpretations, Documentations 10], Pismo Akademii Muzycznej w Krakowie, Kraków, pp. 13-33.

11.Tomaszewski M. (2017), Wokół muzycznej reprezentacji. Muzyka jako „odbicie” świata [Discussing musical representation: Music as a "reflection" of the world], in: Interpretacje dzieła muzycznego w kontekście kultury [Interpreting Musical Works: in Cultural Contexts|, ed. by A. Nowak, vol. 2, Wydawnictwo Akademii Muzycznej w Bydgoszczy, Bydgoszcz, pp. 9-21.

12.Tomaszewski M. (2003), Wprowadzenie do teorii utworu słowno-muzycznego. Próba rozpoznania [Introduction to the theory of vocal-poetic work. An attempt at recognition], 
in: idem, Muzyka w dialogu ze słowem [Music in dialogue with the word], Akademia Muzyczna w Krakowie, Kraków, pp. 129-162.

13.Ulewicz T. (1985), Sarmatyzm [Sarmatism], in: Literatura Polska. Przewodnik encyklopedyczny [Polish Literature. A Thesaurus], vol. 2, Państwowe Wydawnictwo Naukowe, Warsaw, pp. 336-337.

Appendix.

Songs by Witold Friemann to poems by Taras Shevchenko

$\begin{array}{lll}\text { Op. } 18 \text { No. } 2 \text { «Dziewczyna» [Girl] } & 1916 \\ \text { Op. } 26 \text { No. } 1 \text { «Dumy moje» [Songs of Mine] } & 1917 \\ \text { Op. 26 No. } 2 \text { «Pantofelki» [Little Ladies' Shoes] } & 1917 \\ \text { Op. } 26 \text { No. } 3 \text { «Kołysanka» [Lullaby] } & 1917 \\ \text { Op. } 26 \text { No. } 4 \text { «Kukułka»/ «Zazula» [Cuckoo] } & 1917 \\ \text { Op. } 26 \text { No. } 5 \text { «Wspomnienie» [A Memory] } & 1917\end{array}$

Стаття надійшла до редакиії 2.05.2018 р.

\section{А. Новак}

https://orcid.org/0000-0002-4660-7356

\section{ПІСНІ ВІТОЛЬДА ФРІМАННА НА ВІРШ ТАРАСА ШЕВЧЕНКА: ДО ПИТАННЯ ПРО ПОЛЬСЬКО-УКРАЇНСЬКІ ІНСПІРАЦІЇ В МИСТЕЦТВІ}

У статті розглянуто діалог культур як своєрідний взаємовплив іманентних рис традиційного мистецтва через різні форми втілення. Мета роботи - виявити та дослідити культуротворчі та біографічні аспекти появи музичного твору 3 використанням віршів українського поета; визначити вплив елементів культурної спадщини інонаціональних митців; розглянути концепцію композиторського задуму на прикладі вокального циклу Вітольда Фрімана на вірші Тараса Шевченка. У сфері музичної творчості феномен реалізується за допомогою засвоєння іноземних художніх впливів і через створення творів, що своєю появою неначе сплітають елементи культурної спадщини різних за походженням авторів. Вказані вище форми акультурації завше простежуються в музичних артефактах, особливо коли предметом обговорення $\epsilon$ український компонент у польській музичній культурі XIX-XX століть. Задля досягнення мети були використані загальнонаукові методи дослідження (емпіричний та теоретичний) Серед польських музичних артефактів був віднайдений твір, який дає змогу прослідкувати вплив українського літературного компоненту на появу окре-мого вокального циклу.

Актуальність дослідження полягає в пошуку та подальшому аналізі музичних творів, які б розкривали та детально висвітлювали це питання на прикладі твору Вітольда Фрімана. Яскравим втіленням польсько-українського діалогу є Пісні для голосу та фортепіано ор. 18 і ор. 26 Вітольда Фрімана, написані на вірші Тараса Шевченка під час Першої світової війни (1916-1918 рр.). На прикладі цих камерно-вокальних мініатюр досліджуються культуротворчі та біографічні аспекти створення, художня мотивація звернення польського композитора до віршів українського поета, інтерпретує стиль і форму та 3 позицій сьогодення.

Висновки та результати дослідження. Виявлені фактори впливу на формування характеру музичних творів польських композиторів XIX століття. Ознаки жанру української думи, що завдяки аналізу були віднайдені в творах польських композиторів таких як Станіслава Монюшко, Зигмунт Носковський та Свгеніуш Панкєвич, дають підставу засвідчити вагомий вплив українського мелодизму у втіленні композиторського задуму. Охарактеризована 
художня мотивація вибору та використання поезії Тараса Шевченка в піснях Вітольда Фрімана, в контексті феномену взаємопроникнення та впливу обох культур.

Ключові слова: сольна пісня, музика Вітольда Фрімана, вірші Тараса Шевченко

\section{А. Новак}

https://orcid.org/0000-0002-4660-7356

\section{ПЕСНИ ВИТОЛЬДА ФРИМАННА НА СТИХИ ТАРАСА ШЕВЧЕНКО: К ВОПРОСУ О ПОЛЬСКО-УКРАИНСКОМ ИНСПИРАЦИИ В ИСКУССТВЕ}

В статье рассмотрен диалог культур как своеобразное взаимовлияние имманентных черт традиционного искусства через различные формы воплощения. Цель работы - выявить и исследовать культуротворческие и биографические аспекты появления музыкального произведения с использованием стихов украинского поэта; определить влияние элементов культурного наследия инонациональных композиторов; рассмотреть концепцию композиторского замысла на примере вокального цикла Витольда Фримана на стихи Тараса Шевченко.

В сфере музыкального творчества феномен реализуется посредством впитывания инонациональных художественных явлений и через создание произведений; своим появлением будто сплетают элементы культурного наследия различных по происхождению авторов. Вышеуказанные формы аккультурации всегда прослеживаются в музыкальных артефактах, особенно когда предметом обсуждения является украинский компонент в польской музыкальной культуре XIX-XX веков. Для достижения цели были использованы общенаучные методы исследования (эмпирический и теоретический) Среди польских музыкальных артефактов было найдено произведение, которое позволяет проследить влияние украинского литературного компонента на появление отдельного вокального цикла.

Актуальность исследования заключается в поиске и дальнейшем анализе музыкальных произведений, которые бы раскрывали и подробно освещали этот вопрос на примере произведения Витольда Фримана. Ярким воплощением польско-украинского диалога является вокальный цикл Песни для голоса и фортепиано ор. 18 и ор 26 Витольд Фримана, написанные на стихи Тараса Шевченко, который был создан композитором во время Первой мировой войны (1916-1918 гг.). На примере этих камерно-вокальных миниатюр исследуются культуротворческие и биографические аспекты создания цикла, художественная мотивация обращения польского композитора к стихам украинского поэта, интерпретирует стиль и форму и с позиций сегодняшнего дня.

Выводы и результаты исследования. Выявлены факторы влияния на формирование характера музыкальных произведений польских композиторов XIX века. Признаки жанра украинской думы, найденные в произведениях польских композиторов Станислава Монюшко, Зигмунта Носковского и Евгениуша Панкевича, дают основание подтвердить существенное влияние украинского мелодизма в воплощении композиторского замысла. Охарактеризована художественная мотивация выбора и использования поэзии Тараса Шевченко в песнях Витольда Фримана, в контексте феномена взаимопроникновения и влияния обеих культур.

Ключевые слова: сольная песня, музыка Витольда Фримана, стихи Тараса Шевченко.

Anna Novak, Doctor of Arts, Professor, Dean of the Faculty of Composition, Theory of Music and Sound engineering of the Music Academy named after Felix Nowowiejsky (Bydgoszcz).

Анна Новак, доктор мистецтвознавства, професор, декан факультету композиції, теорії музики та звукорежисури Академії музики ім. Фелікса Нововейського (Бидгощ).

e-mail: anowak@amuz.bydgosz 